\title{
STRETEGI PEMBERDAYAAN MASYARAKAT DAN EKONOMI DI MASA PANDEMI MELALUI PROGRAM UMKM BANGKIT DI LAZ YATIM MANDIRI CABANG SIDOARJO
}

\author{
Alfin Maulana \\ Universitas Wijaya Putra Surabaya \\ Agung Bayu Murti \\ Universitas Wijaya Putra Surabaya
}

\begin{abstract}
This study aims to provide a model of community and economic empowerment strategies during the pandemic carried out by LAZ Yatim Mandiri Sidoarjo Branch. So far, most LAZs do have a program focus that is not only for mustahiq, but often the programs seem sudden that are not programmed. Not so for LAZ Yatim Mandiri Sidoarjo Branch which has a very effective community and economic empowerment strategy because it has an efficient management pattern, based on proportionality and a sustainable economy. This is important for research because an empowerment strategy has not been formulated that can be used as a model for other LAZs in the midst of the general economic downturn. This research uses a qualitative approach with the type of field research. Which is collecting data directly to the field using data collection techniques through interviews and documentation. The results of this study indicate
\end{abstract}

Paper type: Research paper

*Corresponding author: alfinmaulana1987@yahoo.ac.id

Received: October 15, 2021; Accepted: November 13, 2021; Available online: December, 06, 2021

Cite this document:

Maulana, A., \& Murti, A. B. (2021). Strategi Pemberdayaan Masyarakat dan Ekonomi di Masa Pandemi Melalui Program UMKM Bangkit di LAZ Yatim Mandiri Cabang Sidoarjo. Jurnal Masharif Al-Syariah: Jurnal Ekonomi dan Perbankan Syariah, 6(3), 833-856. doi:http://dx.doi.org/10.30651/jms.v6i3.10354

Copyright (C) 2021, Jurnal Masharif Al-Syariah: Jurnal Ekonomi dan Perbankan Syariah

http://journal.um-surabaya.ac.id/index.php/Mas/index

This article is licensed under a Creative Commons Attribution-NonCommercial 4.0 International License. 
that the MSME Bangkit Program and assistance carried out by LAZ Yatim Mandiri Sidoarjo Branch has an impact or benefit for the recipients of the program in the form of growing businesses owned by recipients and can improve their standard of living even in a pandemic.

Keywords: Community Empowerment, Amil Zakat Institutions, Covid-19

\begin{abstract}
Abstrak
Studi ini bertujuan memberikan sebuah model tentang strategi pemberdayaan masyarakat dan ekonomi di masa pandemi yang dilakukan oleh LAZ Yatim Mandiri Cabang Sidoarjo. Selama ini kebanyakan LAZ memang memiliki fokus program yang tidak hanya untuk bagi mustahiq saja, namun sering kali programnya terkesan mendadak yang tidak terprogram. Tidak demikian bagi LAZ Yatim Mandiri Cabang Sidoarjo yang memiliki strategi pemberdayaan masyarakat dan ekonomi yang sangat efektif karena memiliki pola pengelolaan yang efisien, berbasiskan proporsional serta ekonomi yang berkelanjutan. Ini menjadi penting untuk dilakukan penelitian karena belum dirumuskannya strategi pemberdayaan yang bisa dijadikan percontohan bagi LAZ yang lain di tengah terjadinya pelemahan ekonomi secara umum. Penelitian ini menggunakan pendekatan kualitatif denga jenis penelitian studi lapangan (field research). Yang mana pengumpulan data secara langsung ke lapangan dengan menggunakan teknik pengumplan data melalui wawancara dan dokumentasi. Hasil penelitian ini menunjukkan bahwa dengan adanya Program UMKM Bangkit serta pendampingan yang dilakukan oleh LAZ Yatim Mandiri Cabang Sidoarjo memiliki dampak atau manfaat bagi penerima program tersebut dalam wujud semakin berkembangnya usaha yang dimiliki oleh penerima serta dapat meningkatkan taraf kehidupan mereka meskipun dalam kondisi pandemi.
\end{abstract}

Kata kunci: Pemberdayaan Masyarakat, Lembaga Amil Zakat, Covid-19

\title{
PENDAHULUAN
}

Sampai saat ini, dampak dari pandemi covid-19 (pandemi effect) masih dirasakan oleh banyak masyarakat, khususnya bagi pelaku bisnis mulai dari mikro hingga makro. Yang mana memiliki dampak ganda, baik bagi pelaku usaha, pangsa pasar serta masyarakat. Meskipun pemerintah sudah melakukan upaya prefentif yang berupa program bantuan langsung, bukan berarti ke depannya tidak ada lagi yang perlu diobati atau diperbaiki. Maka, di sinilah peran Lembaga Amil Zakat (LAZ) yang 
merupakan lembaga filantropi Islam, di mana perannya telah mampu merubah kelemahan menjadi sebuah kekuatan serta mampu merubah sebuah kemiskinan menjadi ketercukupan sebagaimana tujuan dari dibentuknya lembaga tersebut adalah mengangkat derajatnya "mustahiq" menjadi seorang "muzakki".

Adapun pembatasan sosial yang diberlakukan seperti saat ini merupakan bagian dari upaya untuk penanganan serta pencegahan Covid-19, sehingga berdampak pada terbatasnya aktivitas masyarakat yang mengakibatkan terganggunya kegiatan ekonomi masyarakat. Hal ini juga memiliki dampak terhadap sektor perdagangan, kesehatan, transportasi serta pariwisata. Hal ini juga berdampak pada kinerja pertumbuhan ekonomi baik eksternal maupun internal. Dari segi eksternal, adanya pelemahan ekonomi secara global, khususnya pelemahan ekonomi yang dialami oleh lima negara utama, yaitu: Amerika Serikat, Tiongkok, Jepang, India serta Uni Eropa. Terkait dengan kebijakan ekonomi populis, yang mana dengan adanya pandemi Covid-19 ini akan memberikan dampak terhadap perekonomian pada tahun 2020. Sehingga dampak pandemi Covid-19 ini memiliki pengaruh terhadap perekonomian serta bidang perdagangan (Burhanuddin \& Abdi, 2020).

Ada empat seektor di Indonesia yang terdampak akibat pandemi Covid-19, diantaranya rumah tangga, UMKM, perusahaan serto sektor keuangan. Sektor rumah tangga adalah sektor yang pertama kali terdampak, rentan terjadi kesulitan ekonomi serta kesulitan pangan. Oleh karenanya, perlu dilakukan upaya untuk mampu mewujudkan ketahanan ekonomi serta pangan bagi rumah tangga yang terdampak pandemi Covid-19. Sebagaimana yang diungkapkan Menko. Bidang Perekonomian, bahwa pemerintah Indonesia akan memprioritaskan keamanan serta keselamatan masyarakat, selain itu juga menyeimbangkan ketahanan ekonomi nasional di saat pandemi Covid-19 ini (Nasution, dkk, 2020).

Sehingga kondisi yang demikian ini mampu membuat tingkat kemiskinan meningkat. Adapun penduduk miskin pada saat ini di 
Indonesia sekitar 25 juta atau sekitar kurang lebih 9\% dari total penduduk Indonesia. BPS menyebutkan adanya peningkatan jumlah penduduk miskin sekitar 1,28 juta orang per Maret 2020 akibat adanya pandemi Covid-19. Sehinga terjadi peningkatan $0,6 \%$ yang diakibatkan pandemi Covid-19.

Yusuf Qaradhawi dalam kitabnya Fiqh Zakat menyatakan bahwa tujuan serta dampak bagi mustahiq di antaranya adalah membebaskan mustahiq dari kebutuhan, dengan demikian mampu memberikan ketenangan hidup serta mampu beribadah dengan baik sta mampu menepis sifat hasud (iri). Menurut Hafidhuddin (2005) bahwa para ulama' (Imam Syafi'i, Imam Nasa'i dll.) berpendapat bahwa apabila seorang mustahiq mempunyai kemampuan untuk berdagang, maka seyogyanya diberikan modal usaha yang dengan modal tersebut mampu memberikan keuntungan yang nantinya dapat memenuhi kebutuhan pokok mereka (Hafiduddin \& Berkah, 2007).

Melihat dampak dari pandemi Covid-19 yang belum kunjung melandai sehingga memberikan dampak negatif bagi pertumbuhan UMKM yang merupakan denyut nadi perekonomian di Indonesia. Yatim Mandiri selaku Lembaga Amil Zakat (LAZ) sejak bulan Juli 2020telah meluncurkan program UMKM Bangkit. Yang mana UMKM Bangkit adalah program penyaluran dana zakat secara produktif melalui pemberian modal yang bertujuan untuk dapat membantu serta memberdayakan pelaku UMKM khususnya bagi mereka yang terdampak pandemi Covid-19. Adapun modal yang diberikan berupa modal usaha, alat produksi sampai pada keperluan branding. Program ini dilaksanakan di seluruh kantor perwakilan Yatim Mandiri di seluruh Indonesia yang berjumlah 46 perwakilan. Di mana targetnya kurang lebih 250 pelaku UMKM yang akan menerima bantuan program ini. Tidak hanya diberikan modal saja, akan tetapi akan tetap dilakukan monitoring setiap bulan, bantuan terkait dengan pengelolaan manajemen keuangan dan akan coba diberikan akses pemasaran. 
Berdasarkan uraian di atas, peneliti tertarik untuk melakukan kajian atau penelitian terkait dengan strategi pemberdayaan masyarakat dan ekonomi di masa pandemi Covid-19 melalui program UMKM Bangkit di LAZ Yatim Mandiri cabang Sidoarjo. Yang mana penelitian ini dilakukan bertujan untuk melihat lebih jauh mengenai efektivitas strategi pemberdayaan masyarakat dan ekonomi di masa pandemi melalui program UMKM Bangkit di LAZ Yatim Mandiri Cabang Sidoarjo.

Adapun hasil penelitian ini diharapkan dapat memberikan sumbangan pemikiran terkait model strategi pemberdayaan masyarakat dan ekonomi yang berbasiskan zakat produktif yang menjadi percontohan nasional di tengah melemahnya perekonomian dunia.

\section{KAJIAN PUSTAKA}

\section{Pemberdayaan Masyarakat}

Pemberdayaan bisa diartikan dengan pemberi daya (empowerment) atau penguatan (strengthening). Kata "masyarakat" bersumber dari bahas Inggris yaitu society yang memiliki arti kawan, serta bersumber dari bahasa Arab yaitu syirk yang memiliki arti bergaul (Soelaeman, 2009). Pemberdayaan akan membentuk suatu individu dan masyarakat yang mampu untuk menjadi mandiri. Yang mana kemandirian itu meliputi kemandirian berfikir, kemandirian bertindak serta kemandirian mengendalikan apa yang harus mereka lakukan. Sehingga pemberdayaan memiliki tujuan untuk dapat meningkatkan kualitas hidup mereka yang lebih baik bagi seluruh lapisan masyarakat.

Sedangkan menurut Adji, keberdayaan diartikan sebagai kondisi dinamika yang menggambarkan kemampuan akan suatu sistem sosial untuk dapat mewujudkan nilai-nilai atau tujuan yang diinginkannya. Oleh karenanya, pemberdayaan diartikan sebuah usaha (proses) untuk dapat mengembangkan keberdayaan yang ada pada sistem sosial untuk mencapai tujuan secara mandiri (Gitosaputro \& Rangga, 2015). Dalam proses pemberdayaan masyarakat yang merupakan unsur utamanya adalah pemberian kewenangan serta pengembangan kapasitas 
masyarakat, yang mana kedua unsur tersebut tidak dapat dipisahkan (Soetomo, 2011),

Sehingga pada prinsipnya, pemberdayaan merupakan pemberian kekuatan kepada pihak yang kurang atau tidak berdaya (powerles), yang nantinya akan mempunyai kekuatan yang dijadikan modal pengembangan diri. Pemaknaan ini tidak jauh berbeda dengan pendapat Payne dan Shardlow terkait dengan tujuan dari pemberdayaan itu sendiri. Adapun menurut Payne disebutkan bahwa tujuan utama dari pemberdayaan adalah membantu orang untuk memperoleh daya untuk dapat mengambil keputusan serta menentukan tindakan yang akan mereka lakukan, yang berhubungan diri mereka, termasuk di antaranya adalah mengurangi halhal yang menjadi hambatan pada dirinya serta sosial didalam melakukan sebuah tindakan. Sedangkan pendapat Shardlow dapat disimpulkan bahwa pemberdayaan itu menyangkut sebuah permasalahan yang terkait dengan individu maupun kelompok (masyarakat) untuk dapat mengontrol kehidupan mereka sendiri dan mampu untuk dapat menggapai masa depan yang sesuai dengan apa yang mereka inginkan (Ulum, 2016).

Dari pernyataan-pernyataan di atas terkait dengan pemberdayaan, dapatlah ditarik sebuah benang merah bahwa yang dimaksud dengan dengan pemberdayaan ekonomi merupakan upaya untuk pemberian daya ataupun kekuatan dari pihak yang memiliki kekuatan terhadap pihak yang tidak memiliki daya/belum memiliki daya supaya pihak tersebut mampu untuk dapat menyelesaikan masalahnya sendiri, seperti halnya masalah kemiskinan dan ekonomi yang nantinya pihak tersebut mampu untuk mencapai kemandirian dalam segala bidang, baik dari segi ekonomi maupun lainnya.

\section{Lembaga Amil Zakat (LAZ)}

Tahun 2009 telah dikeluarkan UU tentang keberadaan lembaga zakat, yaitu UU. No. 38 Tahun 1999 tentang Pengelolaan Zakat (Hafiduddin \& Berkah, 2007). Dalam UU N0. 38 Tahun 1999 pasal 6 ayat 1 disebutkan bahwa pengelolaan zakat bisa dilakukan oleh BAZ (Badan Amil Zakat) yang dibentuk oleh pemerintah setempat dan pembentukan 
serta pengeloaan zakat oleh masyarakat dapat dilakukan oleh berbagai ormas Islam yang berbentuk LAZ (Lembaga Amil Zakat) (Fakhruddin, 2008).

BAZ merupakan sebuah institusi pengelola zakat yang sepenuhnya dibentuk oleh pemerintah setempat yang kegiatannya meliputi pengumpulan, pendistribusian serta pendayagunaan zakat yang sesuai dengan ketentuan syariat Islam, sedangkan LAZ diartikan sebagai sebuah institusi pengelola zakat yang sepenuhnya dibentuk oleh masyarakat dan nantinya akan dikukuhkan oleh pemerintah untuk dapat melakukan kegiatan yang meliputi pengumpulan, pendistribusian serta pendayagunaan zakat yang sesuai dengan syariat Islam (Fakhruddin, 2008).

LAZ juga dapat diartikan sebagai sebuah organisasi pengelola zakat yang sepenuhnya diprakarsai oleh masyarakat yang memiliki badan hukum tersendiri, yang nantinya akan dikukuhkan oleh pemerintah. Dan Amil Zakat adalah mereka yang melakukan kegiatan yang berhubungan dengan seputar zakat, yang meliputi proses penghimpunan, pemeliharaan sampai hingga proses pendistribusian, serta memiliki tugas pencatatan keluar masuknya zakat yang ada (Hafiduddin \& Berkah, 2007).

\section{Pengelolaan Zakat}

a. Pengertian Pengeloaan Zakat

Menurut UU No. 23 tahun 2011 Pasal 1 Ayat 1 terkait ketentuan umum pengelolaan zakat. Adapun maksud dari pengelolaan zakat merupakan kegiatan terkait perencanaan, pelaksanaan serta pengkoordinasian dalam hal pengumpulan, pendistribusian dan pendaygunaan zakat.

Salah satu tempat yang dapat digunakan dalam pengelolaan dana zakat adalah lembaga zakat. Di mana, lembaga zakat dijadikan sebuah institusi yang dapat menjadikan dana zakat sebagai sumber dana yang cukup potensial untuk dapat dijadikan sebagai penunjang pembiayaan pembangunan, terutama untuk pembangunan ekonomi dan agama yang berguna untuk 
meningkatkan tingkat kesejahteraan masyarakat baik jasmani maupun rohaninya.

b. Tujuan Pengelolaan Zakat

Pada UU No. 23 Tahun 2011 Pasal 3a terkait ketentuan umum pengelolaan zakat, telah dijelaskan tentang tujuan pengelolaan zakat, di antaranya: meningkatkan efektivitas dan efisiensi pelayanan dalam pengelolaan zakat dan meningkatkan kemanfaatan zakat untuk menciptakan kesejahteraan masyarakat serta menanggulangi kemiskinan.

c. Pendistribusian Zakat

Dalam al-Qur'an surat at-Taubah ayat 60, Allah menyatakan bahwa zakat hanya diperuntukkan 8 golongan (ashnaf), yang artinya:

"Sesungguhnya zakat-zakat itu, hanyalah untuk orang-orang fakir, orang-orang miskin, amil, para muallaf yang dibujuk hatinya, untuk (memerdekakan) budak, orang-orang yang berhutang, untuk jalan Allah dan untuk mereka yang sedang dalam perjalanan, sebagai suatu ketetapan yang diwajibkan Allah, dan Allah Maha Mengetahui lagi Maha Bijaksana”.

Dari ayat tersebut, dapatlah difahami bahwa yang berhak untuk menerima atas zakat ada 8 golongan (ashnaf), yaitu: orang-orang fakir (fuqoro'), orang-orang miskin (masaakin), para pengurus zakat (ami), orang-orang yang perlu dibujuk hatinya (muallafah quluubuhum), orang yang terikat dengan hutang (gharim), ibnu sabil, memerdekakan budak (riqob) serta sabilillah.

d. Cara Pengelolaan Zakat

Ada banyak perubahan dalam pengelolaan zakat dari waktu ke waktu. Ada 4 kategori zakat menurut cara pemanfaatan zakat:

1. Zakat konsumtif tradisional, yaitu penyaluran zakat yang diberikan langsung kepada mustahiq untuk pemenuhan kebutuhan konsumsi setiap hari. Model ini bagian dari 
program jangka pendek dalam mengatasi permasalahan kemiskinan umat (Fakhruddin, 2008).

2. Zakat konsumtif kreatif, merupakan penyaluran zakat yang berupa barang bersifat konsumtif yang diperuntukkan membantu orang miskin dalam menyelesaikan permasalahan mereka baik sosial maupun ekonomi.

3. Zakat produktif tradisional, diartikan sebagai penyaluran zakat yang berupa barang-barang produktif, dengan harapan para mustahiq yang menerimanya mampu menciptakan suatu usaha yang dapat memenuhi kebutuhan hidupnya.

4. Zakat produktif kreatif, adalah pendayagunaan zakat dalam bentuk pemberian modal bergulir, baik berupa modal proyek sosial maupun sebagai modal usaha untuk dapat membantu pengembangan usaha para mustahiq yang memiliki usaha.

Ada beberapa ketentuan yang harus dilakukan oleh LAZ dalam mengelola dana zakat yang dilakukan oleh mustahiq:

1. Melakukan Studi Kelayakan

2. Menetapkan jenis usaha produktif

3. Melakukan bimbingan dan penyuluhan

4. Melakukan pemantauan, pengendalian dan pengawasan

5. Mengadakan evaluasi

6. Serta Membuat pelaporan.

\section{Usaha Mikro Kecil dan Menengah (UMKM)}

a. Pengertian

Dalam UU No. 20 tahun 2008 tentang Usaha Mikro Kecil Menengah (UMKM) diartikan sebagai berikut:

1) Usaha mikro merupakan usaha produktif yang dimiliki oleh perorangan dan/atau badan usaha yang dimiliki oleh perorangan yang telah memenuhi kriteria yang sudah diatur dalam UU tersebut.

2) Usaha kecil diartikan sebagai usaha ekonomi produktif yang berdiri sendiri, yang dilaksanakan oleh perorangan ataupun 
badan usaha yang bukan termasuk anak perusahaan atau cabang perusahaan yang telah dimilikinya yang telah memenuhi kriteria usaha kecil yang diatur dalam UU tersebut.

3) Adapun yang dimaksud dengan usaha kecil dan menengah adalah suatu kegiatan usaha dengan cakupan aktivitas yang tidak terlalu besar, memiliki manajemen yang cukup sederhana serta memiliki modal yang terbatas, begitu pula jangkauan pasar yang belum begitu luas.

4) Sedangkan usaha menegah merupakan usaha ekonomi produktif yang berdiri sendiri, yang dimiliki perorangan atau badan usaha yang tidak termasuk anak usaha atau cabang perusahaan yang dimilikinya yang mempunyai jumlah kekayaan bersih atau memiliki hasil penjualan tahunan yang telah diatur dalam UU tersebut.

5) Dunia usaha adalah usaha mikro, kecil, menegah, serta besar yang memiliki aktivitas ekonomi di Indonesia dan memiliki domisili di Indonesia pula. [15]

b. Klasifikasi Usaha Mikro Kecil Menengah

Ada 4 model UMKM bila dilihat dari sudut pandang perkembangan aktivitas bisnis atau usahanya, di antaranya:

1. Livehoo Activities (lapangan kerja baru); UMKM dapat dijadikan sebagai lapangan kerja untuk mencari nafkah, dan sering disebut sebagai sektor informal.

2. Micro Enterprise (sifat kewirausahaan); diartikan sebagai UMKM yang mempunyai jiwa pengrajin namun belum belum mempuyai sifat kewirausahaan.

3. Small Dynamic Enterprise; diartikan sebagai UMKM yang sudah memeiliki jiwa kewirausahaan serta mampu diberi pekerjaan baik bersifat subkontrak maupun ekspor. 
4. Fast Moving Enterprise; diartikan sebagai UMKM yang sudah mempunyai jiwa kewirausahaan serta mampu untuk menjadi Usaha Besar.

c. Kekuatan dan kelemahan Usaha Mikro

Agar UMKM dapat berkembang di masa yang mendatang, maka UMKM harus mampu untuk memanfaatkan potensi dipunyai. Di antaranya:

1. Memiliki potensi sebagai penyedia lapangan kerja pada sektor industri kecil, sebaba dianggap mampu menyerap tenaga kerja baru.

2. Sebagai sumber wirausaha baru yang bisa mampu medorong munculnya wirausaha baru lainnya.

3. Memiliki potensi pasar yang baik.

4. Memiliki sistem manajemen yang terkesn sederhana dan fleksibel dalam menghadapi tantangan perubahan pasar.

5. Memiliki potensi yang tinggi untuk dapat berkembang serta mudah untuk menerima pembinaan.

Ada 2 kalsifikasi faktor penghambat dan permasalahan dalam UMKM, yaitu:

1) Faktor internal; yang dianggap sebagai masalah klasik dalam UMKM, di antaranya:

a) Terbatasnya tingkat SDM

b) Lemah dalam pemasaran produk, hal ini disebabkan UMKM hanya fokus pada aspek produksi tanpa memperhatikan aspek pemasaran

c) Lemahnya kepercayaan (trust) oleh konsumen kepada pengrajin industri kecil.

2) Faktor eksternal; masalah yang timbul dari developer (pengembang) serta pembina UMKM.

Dari dua faktor tersebut di atas akan muncul perbedaan dari sisi perbankan, BUMN serta lembaga pendamping yang akan memberikan pembiayaan dengan ketentuan yang harus mampu 
dipenuhi oleh UMKM sebagai faktor penunjang atau penentu dalam pemberian pembiayaan.

\section{METODE PENELITIAN}

Dalam penelitian ini menggunakan penelitian studi lapangan (field research). Yang mana penelitian studi lapangan (field research) merupakan pengumpulan data secara langsung datang ke lapangan dengan menggunakan teknik pengumpulan data melalui wawancara (interview) serta dokumentasi.

Adapun pendekatan yang digunakan dalam penelitian ini adalah penelitian kualitatif. Yang mana prosedur dalam penelitian ini akan menghasikan data deskriptif berupa narasi tertulis atau lisan dari orangorang atau perilaku atau gejala yang diamati di lapangan.

Adapun data yang digunakan dalam penelitian ini adalah data kualitatif, yang mana data kualitatif ini dijadikan prosedur penelitian yang menghasilkan data deskriptif berupa kata-kata tertulis atau lisan dari orang-orang atau gejala yang dapat diamati.

Sumber data dalam penelitian terdiri dari dua data, yaitu data primer dan data sekunder. Sumber data primer dalam penelitian ini adalah pelaku usaha yang telah menerima program UMKM Bangkit serta pihak LAZ Yatim Mandiri Cabang Sidoarjo. Sedangkan data sekunder dalam penelitian ini bersumber dari artikel yang terkait dengan strategi pemberdayaan masyarakat dan ekonomi di masa pandemi melalui program UMKM Bangkit di LAZ Yatim Mandiri cabang Sidoarjo.

Dan adapun teknik pengumpulan data dalam penelitian ini menggunakan teknik observasi partisipasi, wawancara (interview) serta dokumentasi.

\section{HASIL DAN PEMBAHASAN}

\section{Gambaran Umum LAZ Yatim Mandiri}

Yatim Mandiri merupakan Lembaga Amil Zakat Nasional (LAZNAS) yang dimiliki oleh masyarakat Indonesia yang melakukan khdimat untuk dapat mengangkat harkat sosial kemanusiaan yatim dhuafa melalui dana 
ZISWAF (Zakat, Infaq, Shadaqah dan Wakaf) serta dana lainnya yang bersifat halal dan legal, baik bersumber dari perorangan, kelompok maupun lembaga/perusahaan.

Kehadirannya berawal dari sebuah kegelisahan beberapa aktivis panti asuhan yang ada di Surabaya, mereka adalah Sahid Has, Sumarno Hasan Sadzili, Syarif Mukhodam dan Moch. Hasyim ketika melihat anakanak yatim yang telah lulus SMA di Panti Asuhan. Di mana tidak semua panti asuhan mampu untuk menyekolahkan para anak binaannya sampai ke jenjang yang lebih tinggi (perguruan tinggi) atau belum mampu untuk memberikan lapangan pekerjaan bagi mereka, sehingga sebagian besar dari mereka dipulangkan kembali kepada orang tuanya yang masih ada. Yang mana ketika mereka pulang kembali ke rumahnya masing-masing, maka kehidupan mereka kembali seperti sedia kala. Adanya kondisi seperti ini yang menjadikan mereka berfikir bagaimana caranya anak-anak ini mampu hidup mandiri tanpa harus bergantung kepada orang lain.

Sehingga mereka merancang sebuah yayasan yang bergerak pada bidang pendidikan anak yatim purna suh dari panti asuhan melalui program yang mengikutsertakan anak-anak yatim melalui kursus keterampilan. Yayasan ini berjalan dengan baik dan potensi yang dimiliki anak yatim yang harus dimandirikan dengan cukup banyak. Berawal dari mimpi itulah (memandirikan anak-nak yatim), maka pada tanggal 31 Maret 1994 terbentuklah sebuah yayasan yang diberi nama Yayasan Pembinaan dan Pengembangan Panti Asuhan Islam dan Anak Purna Asuh (YP3IS). Yang kemudian pada tanggal tersebut dijadikan sebagai hari lahir yayasan tersebut.

Dalam perjalanannya, YP3IS mengalami perkembangan yang cukup baik, berkat adanya dukungan dana dari masyarakat serta semakin profesional dalam memandirikan anak-anak yatim melalui programprogram yang sudah dilaksanakan. Setelah dilakukannya beberapa perubahan, baik perubahan dalam susunan kepengurusan maupun perubahan dalam hal manajemen dengan tujuan untuk memperluas 
kemanfaatan dalam memandirikan anak yatim, maka dalam rapat diputuskan untuk mengganti nama yayasan menjadi Yatim Mandiri.

Dan pada tanggal 22 Juli 2008 Yatim Mandiei telah terdaftar di Depkumham dengan nomor: AHU-2413.AH.01.02.2008. Dengan adanya nama baru Yatim Mandiri diharapkan mampu untuk menjadi lembaga pemberdaya anak yatim yang handal dan kuat di negerinya sendiri. Yatim Mandiri juga telah resmi terdaftar sebagai Lembaga Amil Zakat Nasional yang berdasarkan SK. Kemenag RI No. 185 tahun 2016. Dan sampai saat ini Yatim Mandiri sudah memiliki 46 kantor layanan di 14 Provinsi di Indonesia. Dengan adanya program kemandirian yang dimilikinya, diharapkan Yatim Mandiri semakin berkembang lebih baik serta mampu dapat menebar manfaat yang lebih luas.

\section{Program Yatim Mandiri}

LAZ Yatim Mandiri merupakan salah satu lembaga amil zakat yang berusaha untuk mampu memberikan layanan secara profesional yang berkaitan dengan pengumpulan, penyimpanan, penjagaan pencatatan serta pendistribusian harta zakat.

Adapun lokasi proyek Yatim Mandiri terus berkembang dan tidak lagi terbatas hanya di pulau Jawa saja, dan sudah meluas di seluruh wilayah Indonesia. Sehingga kegiatannya pun bergeser dari yang hanya program pada bidang sosial menjadi pengembangan pemberdayaan masyarakat dan ekonomi. Adapun program-program Yatim Mandiri dalam pemberdayaan masyarakat:

a. Program Pendidikan

1) Sanggar Al-Qur'an

Program yang berfokus pada menanamkan edukasi karakter yang sangat penting bagi setiap insan. Di Sanggar Al-Qur'an Yatim Mandiri, anak yatim dan dhuafa mendapatkan pembinaan akhlak dan tata cara membaca Al-Qur'an yang baik dan benar oleh ustadz dan ustadzah yang berpengalaman. Adapun Tujuan dari program ini adalah anak-anak binaan memiliki karakter yang baik, memahami 
Al-Qur'an dengan baik dan benar, serta menguasai dasardasar Syariat I slam yang menjadi pedoman hidupnya.

Dalam pelaksanaannya, Sanggar Al-Qur'an memperhatikan kaidah-kaidah pembelajaran yang religius, edukatif dan disiplin dalam rangka membangun mentalitas santri yang mampu mencetak generasi Islam masa kini yang berwawasan luas, berhati nurani dan peduli kepada manusia lainnya.

2) Kampus Kemandirian

Dalam menjawab tantangan zaman, Yatim Mandiri menghadirkan "Kampus Kemandirian" dengan mengedepankan pendidikan unggul, berbudi pekerti luhur, mengembangkan penelitian yang substansial, mempunyai nilai kompetitif, dan mencetak lulusan yang solutif di tengah kehidupan bermasyarakat.

Secara garis besar, Kampus Kemandirian Yatim Mandiri mengedepankan nilai-nilai profesionalitas, metode efektif dalam setiap perkuliahan, pembelajaran yang variatif dan terarah untuk mencapai tujuan mulia yakni membangun generasi mandiri. Berikut nama-nama Kampus Kemandirian di bawah bimbingan Yayasan Yatim Mandiri: Sekolah Tinggi Agama Islam An-Najah Indonesia Mandiri (STAINIM), Universitas Insan Cendekia Mandiri (UICM) dan Institut Teknologi Insan Cendekia Mandiri (ITICM).

3) ICMBS

Program ini merupakan program yang menitikberatkan pada pembinaan keislaman, kepemimpinan dan prestasi akademik siswa. Insan Cendekia Mandiri Boarding School (ICMBS) memadukan gabungan kurikulum diknas, kurikulum khas Insan Cendekia Mandiri Boarding School dan kurikulum Internasional, sehingga akan lahir lulusan terdidik, mandiri dan berwawasan Internasional. 
Dalam rangka mengembangkan potensi siswa, Insan Cendekia Mandiri Boarding School (ICMBS) memiliki motto "Mencetak Generasi Pemimpin Dunia" dengan mengedepankan 3 aspek dalam sendi pendidikan, yakni membangun kapasitas belajar, pembelajaran learning style dan menerapkan sikap thinking style dalam bersikap.

Insan Cendekia Mandiri Boarding School (ICMBS) menjadi kawah candradimuka bagi setiap peserta didiknya dalam upaya membangun nilai-nilai kemandirian dan menggapai cita-cita. Mereka adalah anak-anak yatim berprestasi tingkat SMP dan SMA yang terpilih dari seluruh Indonesia, mendapatkan pendidikan formal gratis dan berkualitas.

4) Rumah Kemandirian

Dengan menggabungkan program Sanggar Genius dan Sanggar al-Qur'an menjadi kesatuan program "Rumah Kemandirian". Yatim Mandiri memfasilitasi bagi anak-anak yatim dan dhuafa yang masih mengeyam pendidikan di bangku SD/MI atau sederajat, untuk dapat mengasah kemampuan yang ada, baik bersifat akademik, agama maupun bakat yang lainnya.

Dengan mengadopsi pembinaan asrama, program ini memiliki basis keluarga. Dimana kepala asrama akan memposisikan diri sebagai pengganti orang tua mereka. Yang mana program ini memiliki visi yang mulia, yaitu "Menyiapkan Generasi Mandiri dan Berprestasi".

Selama program ini berlangsung, anak-anak binaan memperoleh beasiswa secara penuh dan tidak harus mengeluarkan uang sedikit pun. Adapun fasilitas yang disediakan berupa biaya pendidikan, asrama, makan-minum, kesehatan, alat sekolah, seragam, serta tabungan dalam jumlah jutaan rupiah yang akan ditunaikan pada akhir masa pendidikan. 
5) Beasiswa Yatim Mandiri (Bestari)

Yatim Mandiri bagian dari lembaga filantropi Islam yang memiliki tujuan agar fokus dalam kemandirian dan pendidikan anak yatim serta dhuafa, memberikan program "Beasiswa Yatim Mandiri (BESTARI)" yang diperuntukkan bagi siswa kurang mampu yang memiliki perstasi.

Program ini diperuntukkan untuk semua tingkatan pendidikan, mulai dari SD, SMP serta SMA di seluruh Indonesia. Adapun tujuan dari program ini adalah pemberian beasiswa kepada anak yatim dan dhuafa sebagai bentuk dukungan yang diberikan kepada mereka untuk mencapai mimpinya dan dapat mengukir banyak prestasi di tingkat pendidikannya.

6) Alat Sekolah Ceria

Pemenuhan akan perlengkapan sekolah merupakan salah satu faktor yang dapat memacu semangat peserta didik dalam mengukir prestasinya.

Oleh karenanya, Yatim Mandiri menginisiasi program "Alat Sekolah Ceria (ASA)" yang diperuntukkan bagi anak yatim dan dhuafa yang membutuhkan agar dapat meningkatkan semangat mereka dalam belajar.

Program ini diharapkan dapat mengurangi kendala belajar mereka, berupa tas sekolah, alat tulis, buku, penggaris dan lain sebagainya. Program ini setiap tahunnya digulirkan sebanyak 5000 paket lebih dengan jumlah penerima manfaat yang tersebar di walayah Indonesia (SD, SMP, SMA).

7) Sanggar Genius

Program ini lahir berawal dari ketergerakan Yatim Mandiri melihat anak yatim dan dhuafa yang ada di daerha belum bisa menikmati pendidikan secara utuh. Termasuk di dalamnya adalah pendampingan dan bimbingan di luar pelajaran yang diberikan oleh sekolah. Begitu pula bagi 
masyarakat yang memiliki ekonomi menengah ke bawah, masih banyak yang belum mampu mendapatkan pendampingan serta

b. Program Pemberdayaan

1) Mandiri Entrepreneur Center (MEC)

Yatim Mandiri mempunyai visi-misi untuk memandirikan anak yatim dan dhuafa demi generasi muda di kemudian hari. Program Yatim Mandiri untuk memandirikan generasi muda adalah "Mandiri Entrepreneur Center (MEC)". Program ini memberikan bekal kepada generasi muda yatim dan dhauafa berupa skill, pengembangan mental mandiri dan akses menuju dunia usaha atau wirausaha. Sudah hampir 1.800 anak yatim dan dhuafa telah diberikan diberikan program ini serta berhasil mandiri secara ekonomi sebagai pekerja profesional maupun wirausaha. Dan memiliki dampak positif bagi lingkungan sekitarnya.

2) Kampung Mandiri

Adanya potensi desa yang melimpah dan mampu dikelola namun belum dapat mensejahterakan masyarakat sekitar. Melalui ini, Yatim Mandiri mempunyai program yang berbasiskan pemberdayaan memiliki kearifan lokal berupa "Kampung Mandiri".

Kampung Mandiri adalah pemberdayaan sekitar wilayah desa yang memiliki tujuan dalam optimalisasi potensi agro di sebuah desa melalui intervensi pembentukan kelompok usaha bersama. Melalui program ini diharapkan masyarakat mempunyai sumber penghasilan yang bersumber dari lingkungan sekitar. Adapun aktivitas dimulai dari melakukan mapping potensi desa, survei calok penerima, penyamaan visi-misi kelompok, pembentukan kelompok, pelatiahn, pembinaan rutin, penyaluran modal usaha bersama, samapi pada pembentukan badan hukum. 
Goal dari program ini adalah memandirikan masyarakat desa dengan segala potensi yang dimiliki demi kemajuan wilayah tersebut.

3) Bunda Mandiri Sejahtera (BISA)

Program ini bagian dari upaya Yatim Mandiri untuk dapat mensejahterakan keluarga yatim dan dhuafa. Dalam program ini meliputi pembinaan kelslaman, pengasuhan serta pemberdayaan ekonomi. Pada program ini juga memiliki fokus dalam pemberdayaan bunda yatim, yakni membuat kelompok usaha bersama dengan pendamping pengusaha profesional pada bidangnya.

Adapun bantuan yang diberikan diperuntukkan sebagai set up uasaha, memberikan modal usaha dan operasional usaha. Dengan harapan, adanya program ini mampu mensejahterakan keluarga yatim dan mampu mandiri.

c. Program Kemanusiaan

1) Bedah Rumah

Tidak semua orang memiliki kesempatan untuk mempunia rumah yang dinginkan. Diantara faktor yang mempengaruhi adalah permasalahan ekonomi atau karena keadaan yang memaksa mereka untuk lebih mendahulukan kebutuhan hidupnya yang bersifat primer.

Masih banyak masyarakat miskin yang tinggal di daerah kumuh, menempati tempat tinggal yang kurang layak serta lokasinya yang tidak layak. Oleh karena itu Yatim Mandiri meluncurkan program "Bangun Rumah Harapan" yang diharapkan mampu menjadi solusi dalam menghadirkan rumah yang layak huni serta sehat bagi keluarga miskin yatim dan dhuafa.

2) Bantuan Langsung Mustahik

Disparitas sosial sering kali kita ketahui di beberapa wilayah. Untuk itu, diperlukan kerjasama antar pihak dalam upaya 
menanggulangi permasalah tersebut. Salah satu konsep yang efektif untuk mengatasi masalah tersebut adalah konsep tolong menolong, dari mereka yang surplus dana kepada mereka yang defisit dana.

Adapun zakat, infaq dan sedekah yang sudah dihimpun oleh Yatim Mandiri akan didistribusikan dalam beberapa program, di antaranya adalah "Bantuan Langsung Mustahik". Program ini merupakan program layanan ekstra kepada masyarakat sebagai bentuk kepedulian Yatim Mandiri terhadap masyarakat miskin dan dhuafa dalam meringakan beban mereka (mustahik). Yang mana program ini fokus pada bidang pendidikan, kesehatan serta ekonomi.

3) Yatim Mandiri Peduli Bencana (YMPB)

Bencana memberikan dampak, baik moral maupun material. Yatim Mandiri ikut andil dalam tanggap bencana, mulai dari evakuasi, distribusi bantuan makanan, layanan kesehatan, layanan psikososial sampai padapemulihan pasca bencana. Oleh karena itu diperlukan kerjasama dan saling tolong menolong yang saling bersinergi dalam meringakan beban sesama yang membutuhkan.

\section{Program UMKM Bangkit LAZ Yatim Mandiri}

LAZ Yatim Mandiri cabang Sidoarjo melakukan gerakan UMKM Bangkit yang merupakan program yang dapat dijadikan solusi bagi masyarakat yang rentan terdampak pandemi. Program ini diluncurkan untuk dapat dijadikan solusi bagi masyarakat yang rentan terdampak pandemi Covid-19. UMKM Bangkit adalah program yang menyalurkan dana zakat secara produktif melalui pemberian modal yang bertujuan untuk membantu dan memberdayakan para pelaku UMKM, khususnya UMKM yang terdampak pandemi Covid-19. Adapun modal yang diberikan bisa berupa modal usaha, alat produksi, serta keperluan branding. 
Pada program UMKM Bangkit yang dilaksanakan di wilayah kerja LAZ Yatim Mandiri cabang Sidoarjo yakni area kabupaten Sidoarjo terdapat dua skema yang digalakkan:

1. Bergulir

Skema ini diinisiasi yang bertujuan untuk pengembangan UMKM bagi masyarakat miskin yang terdampak pandemi Covid-19. Pada skema ini sejak bulan Agustus 2020 sudah terdapat 9 pelaku UMKM, dengan rincian 7 penerima skema ini berada di wilayah Kramat Jeguh-Taman dan 2 penerima berada di wilayah Krembung.

Dalam skema ini, pelaku UMKM yang menerima program ini memperoleh pendanaan dengan minimal Rp. 500.000 - Rp. 3.000.000, tidak hanya modal yang diberikan, sebagian penerima manfaat program ini juga akan dimonirtoring setiap bulan, diberikan bantuan terkait manajemen keuangan serta coba dibukakan akses pemasaran terkait dengan produk mereka.

2. Hibah

Skema ini diberikan dengan tujuan untuk membantu masyarakat yang terdampak pandemi Covid-19 berupa kebutuhan sehari-hari. Dalam skema ini sejak bulan Agustus 2020 sudah hampir 4 masyarakat terdampak yang sudah menerima program ini. Dengan rincian 1 penerima dari Cemengkalang-Sidoarjo dan 3 penerima dari Tulangan-Sidoarjo.

Dalam skema ini, masyarakat yang menerima program ini tidak hanya menerima kebutuhan pokok berupa sembako, tapi juga menerima obat-obatan yang mereka butuhkan selama kondisi pandemi seperti saat ini.

Efektivitas Program UMKM Bangkit terhadap Pemberdayaan Masyarakat dan Ekonomi

Lokasi atau wilayah dalam penelitian ini adalah kabupaten Sidoarjo, dikarenakan kabupaten Sidoarjo merupakan salah satu kabupaten yang mempunyai sektor UMKM cukup banyak, sehingga banyak sekali UMKM yang terdampak oleh pandemi Covid-19. 
Program UMKM Bangkit ini memiliki dampak yang cukup besar secara langsung kepada mustahik, yang mana di masa pandemi Covid-19 ini, khususnya bagi masyarakat yang mata pencahariannya sangat bergantung pada keramaian, sehingga pendapatan mereka juga terdampak, sehingga tidak jarang dari mereka yang harus rela kehilangan akan mata pencaharian mereka secara satu persatu.

Dalam program UMKM Bangkit ini memiliki fokus program pada pemberdayaan ekonomi serta ketahanan pangan bagi masyarakat terdampak. Yang mana, dalam tahap awal program ini fokus pada pemberdayaan pada pelaku UMKM melalui skema bergulir. Di mana program ini sangat cukup membantu para pelaku UMKM yang menjadi sumber utama penghasilan mereka. Tidak sedikit dari para pelaku UMKM yang bersyukur dengan program UMKM Bangkit ini, karena dengan program ini membantu keberlangsungan usaha mereka. Program ini tidak hanya berfokus pada pemberdayaan ekonomi pelaku UMKM saja, tetapi juga berfokus pada ketahanan pangan bagi masyarakat yang terdampak pandemi Covid-19. Tidak sedikit dari mereka penerima merasa bersyukur dengan adanya program ini, karena dengan program ini mampu membantu mereka untuk dapat memenuhi kebutuhan mereka yang bersifat primer.

Adapun kriteria yang ditekankan pada program UMKM Bangkit yang tidak hanya sekedar ingin melangsungkan usaha mereka saja, akan tetapi LAZ Yatim Mandiri cabang Sidoarjo juga menilai akan kesungguhan serta komitmen bagi penerima program ini, baik skema Bergulir maupun Hibah dalam menjalankan program UMKM Bangkit ini. Karena salah satu indikator penilaian keberhasilan program ini tergantung pada kesungguhan serta kegigihan masayarakat dalam mengelola dan mengembangkan modal yang bersumber dari zakat serta ilmu yang telah diberikan, begitu pula komitmen untuk tidak menjadikan modal bergulir sebagai modal konsumtif bagi penerima skema Bergulir yang pada akhirnya akan berhenti di tengah jalan. 
Dengan banyaknya manfaat yang telah dirasakan oleh masyarakat secara luas, program UMKM Bangkit bisa menjadi salah satu model pendistribusian zakat produktif yang dapat membantu masyarakat dan memberdayakan penerima manfaat dan diharapkan akan terus berkembang, baik di masa pandemi maupun sesudah pandemi Covid-19.

\section{KESIMPULAN DAN KETERBATASAN}

Berdasarkan uraaian dan penjelasan di atas yang telah diteliti dan dirangkum oleh peneliti, maka peneliti mengambil beberapa kesimpulan yang terkait "Efektivitas Strategi Pemberdayaan Masyarakat dan Ekonomi di Masa Pandemi melalui Program UMKM Bangkit di LAZ Yatim Mandiri Cabang Sidoarjo" untuk memberdayakan para pelaku UMKM yang terdampak pandemi Covid-19 serta memberikan ketahanan ekonomi yang mengalami kesulitan dari segi ekonomi.

Adapun pelaksanaan program UMKM Bangkit pada masa pandemi Covid-19 yang dilaksanakan oleh LAZ Yatim Mandiri Cabang Sidoarjo melalui 2 program (skema) yang digalakkan, yaitu: 1) UMKM Bangkit dengan skema Bergulir, merupakan program pemberdayaan bagi pelaku UMKM dengan bentuk pemberian modal, monitoring setiap bulan, bantuan manajemen keuangan serta dibukakan akses pemasaran, 2) UMKM Bangkit dengan skema Hibah, merupakan program yang diberikan kepada masyarakat yang terdampak pandemi Covid-19 secara ekonomi. Dalam skema ini, masyarakat yang menerima program ini tidak hanya menerima kebutuhan pokok berupa sembako, tapi juga menerima obat-obatan yang mereka butuhkan selama kondisi pandemi seperti saat ini.

\section{DAFTAR PUSTAKA}

Burhanuddin, C. I., \& Abdi, M. N. 2020. Ancaman Krisis Ekonomi Global Dari Dampak Penyebaran Virus Corona (Covid-19), 17

Fakhruddin, F. 2008. Fiqh dan Manajemen Zakat di Indonesia.UIN-Maliki Press. Malang.

Gitosaputro, S., \& Rangga, K. K. 2015. Pengembangan dan Pemberdayaan Masyarakat: Konsep, Teori dan Aplikasinya di Era Otonomi Daerah. Graha Ilmu. Yogyakarta. 
Hafiduddin, D., \& Berkah, A. H. 2007. Bertambah: Gerakan Membudayakan Zakat, Infaq, Sedekah, dan Wakaf. Gema Insani, Jakarta.

Nasution, D. A. D., Erlina, E., \& Muda, I. 2020. Dampak Pandemi Covid-19 terhadap Perekonomian Indonesia, Jurnal Benefita, Vol. 5, No. 2, 212.

https://www.yatimmandiri.org/uploads/majalah/b835bc3a6dca32860f0c585 e416ed4a1.pdf.)

Soelaeman, M. 2009. Sosiologi: Suatu Pengantar. PT. Raja Grafindo, Jakarta.

Soetomo, A. 2011. Pemberdayaan Masyarakat. Pustaka Belajar. Yogyakarta.

Ulum, M. C. 2016. Perilaku Organisasi Menuju Orientasi Pemberdayaan. Universitas Brawijaya Press. Malang

UU No. 20 Tahun 2008 tentang UMKM 